\title{
Chemokines in the limbal form of vernal keratoconjunctivitis
}

Ahmed M Abu El-Asrar, Sofie Struyf, Soliman A Al-Kharashi, Luc Missotten, Jo Van Damme, Karel Geboes

\begin{abstract}
Backgroundlaims-Chemokines are a family of low molecular weight cytokines that attract and activate leucocytes. The CC chemokines act on eosinophils, basophils, monocytes, and lymphocytes, suggesting that they play an important part in allergic diseases. The aims of this study were to investigate the expression of the CC chemokines, RANTES, eotaxin, monocyte chemotactic protein (MCP) 1, MCP-2, and MCP-3 in the conjunctiva of patients with vernal keratoconjunctivitis (VKC) and to determine the cellular source of these chemokines.
\end{abstract}

Methods-Conjunctival biopsy specimens from nine subjects with active VKC, and six control subjects were studied by immunohistochemical techniques using a panel of monoclonal and polyclonal antibodies directed against RANTES, eotaxin, MCP-1, MCP-2, and MCP-3. The phenotype of inflammatory cells expressing chemokines was examined by sequential double immunohistochemistry.

Results-In the normal conjunctiva, superficial epithelial cells showed a constitutive, weak cytoplasmic expression of eotaxin. Few inflammatory cells in the perivascular areas expressed RANTES, MCP-1, MCP-2, and MCP-3. In VKC specimens, the epithelium showed intense cytoplasmic eotaxin staining in all cells, and cytoplasmic RANTES staining mainly in the superficial layers. Furthermore, RANTES and eotaxin were expressed on the vascular endothelium mainly in the upper substantia propria. Compared with normal controls, VKC specimens showed significantly more inflammatory cells expressing RANTES, eotaxin, MCP-1, and MCP-3 ( $<<0.001,0.0028,0.0092$, and $<0.001$, respectively). In VKC specimens, the numbers of inflammatory cells expressing RANTES were significantly higher than the numbers of inflammatory cells expressing eotaxin, MCP-1, and MCP-2 (all p values $<0.001$ ). Colocalisation studies revealed that the majority of inflammatory cells expressing chemokines were CD68 positive monocytes/ macrophages.

Conclusions-These results demonstrate an increase in the expression of RANTES, eotaxin, MCP-1, and MCP-3 in the conjunctiva of patients with VKC compared with control subjects. These data suggest a potential role for these chemokines in the pathogenesis of VKC. Antagonists of chemokine receptors may provide new therapeutic modalities in VKC. (Br F Ophthalmol 2000;84:1360-1366)

Vernal keratoconjunctivitis (VKC) is a chronic seasonally exacerbated bilateral external allergic ocular inflammation that primarily affects children and young adults, with a male predominance. Itching is the most frequent symptom of VKC. Excessive tearing, tenacious stringy mucous discharge, photophobia, and burning or foreign body sensation are common symptoms. There are three major forms of the disease: palpebral, limbal, and mixed. The classic sign of palpebral VKC is the giant papillae or cobblestones in the upper tarsal conjunctiva. The limbal form is characterised by gelatinous infiltrates of the limbus. Corneal findings are common and include punctate epithelial keratitis, epithelial erosions, corneal ulcers, and plaque formation. ${ }^{12}$

The main histological feature of VKC consists of infiltration of the conjunctival epithelium and substantia propria by inflammatory cells, including eosinophils, basophils, mast cells showing membranous IgE staining, B lymphocytes organised as small lymphoid follicles, $\operatorname{IgA}^{+}, \operatorname{IgG}^{+}, \operatorname{IgM}^{+}$, and $\operatorname{IgE}^{+}$plasma cells, $\mathrm{CD} 4^{+} \mathrm{T}$ lymphocytes expressing $\mathrm{T}$ helper 2 (TH2)-type cytokines, macrophages, dendritic cells, and dendritic cells bearing $\operatorname{IgE} .^{3-8}$ The proportions of infiltrating cells of different phenotypes in VKC were characterised in several studies. ${ }^{45}$ Eosinophil recruitment to the conjunctiva is thought to play a central part in the pathophysiology of VKC. Activated eosinophils release strong basic cytotoxic proteins such as major basic protein, eosinophil cationic protein, eosinophil peroxidase, and eosinophil derived neurotoxin which are released in the conjunctiva and tear fluid and damage the conjunctival and corneal epithelium. ${ }^{9-11}$ More recently, eosinophils were recognised as a source of proinflammatory cytokines, which may act to perpetuate the local immune response. ${ }^{12}$

The selective recruitment of eosinophils to sites of inflammation is controlled by cytokines, and adhesion molecules. It has been hypothesised that selective recruitment of eosinophils involves the expression of the endothelial adhesion molecule, vascular cell adhesion molecule-1 (VCAM-1), which promotes the adhesion of eosinophils, lymphocytes, monocytes, and basophils, but not neutrophils, to the vascular endothelium. This selectivity is conferred by the counterligand for VCAM-1, very 
Table 1 Monoclonal and polyclonal antibodies used in this study

\begin{tabular}{llll}
\hline Antibody & Specificity & Working dilution & Source \\
\hline Anti-human RANTES (mc) & RANTES & $1: 20$ & Pepro Tech \\
Anti-human eotaxin (pc) & Eotaxin & $1: 20$ & Pepro Tech \\
Anti-human MCP-1 (mc) & MCP-1 & $1: 20$ & R \& D systems \\
Anti-human MCP-2 (mc) & MCP-2 & $1: 20$ & R \& D systems \\
Anti-human MCP-3 (mc) & MCP-3 & $1: 20$ & Pepro Tech \\
CD68 (mc) & Macrophages & $1: 1000$ & Dakopatts \\
CD3 (mc) & Pan T cell & $1: 400$ & Dakopatts \\
Factor VIII related antigen (mc) & Endothelial cells & $1: 20$ & Dako \\
\hline
\end{tabular}

${ }^{\star}$ Location of manufacturers: Pepro Tech, Rocky Hill, NJ, USA; R \& D systems Europe Ltd, Abingdon, UK; Dakopatts A/S, Copenhagen, Denmark; Dako, CA, USA.

RANTES $=$ regulated upon activation, normal $\mathrm{T}$ cell expressed and secreted; $\mathrm{MCP}=$ monocyte chemotactic protein; $(\mathrm{pc})=$ polyclonal antibodies; $(\mathrm{mc})=$ monoclonal antibodies .

late activation antigen-4 (VLA-4), which is present on all circulating leucocytes except neutrophils. ${ }^{13}$ The expression of VCAM-1 is selectively induced by the $\mathrm{TH} 2$ derived cytokines interleukin 4 (IL-4), and IL-13. ${ }^{14}{ }^{15}$ Several studies demonstrated increased expression of adhesion molecules in the different clinical subtypes of allergic conjunctivitis including VKC. ${ }^{516}$ The development of tissue eosinophilia is also probably dependent on the presence of selective priming cytokines such as IL-3, IL-5, and granulocytemacrophage colony stimulating factor. ${ }^{18}$

Recently, a family of chemoattractant peptides, termed chemokines, has been recognised to play an important part in the migration and transendothelial passage of leucocytes. ${ }^{19-21}$ These chemokines are subdivided into four subfamilies based upon the configuration of the N-terminal conserved cysteine residues: (1) The CXC subfamily is characterised by the presence of two N-terminal conserved cysteine residues separated by a single amino acid. (2) The CC subfamily contains two conserved cysteines in juxtaposition. (3) The C subfamily has only one cysteine in the conserved region. (4) The members of the CX3C subfamily are membrane anchored glycoproteins with a C-terminal lectin-like sequence and an $\mathrm{N}$-terminal chemokine-like structure in which the two cysteine residues are separated by three non-conserved residues.

The CC chemokines, RANTES (regulated upon activation, normal $\mathrm{T}$ cell expressed and secreted), eotaxin, monocyte chemotactic protein (MCP) 1, MCP-2, and MCP-3 have been shown to have the capacity to act on monocytes, lymphocytes, basophils, and eosinophils, but not neutrophils. ${ }^{19-21}$ These chemokines may have the potential to play a special part in attracting these cells to the conjunctiva in VKC. The aim of this study, therefore, was to elucidate the role of these chemokines in the pathogenesis of VKC. We used immunohistochemical techniques to determine whether these proteins could be detected in conjunctival biopsies from individuals with VKC and normal controls and to investigate the cellular source of these chemokines.

\section{Patients and methods}

PATIENTS

Nine consecutive patients with active VKC seen at the outpatient clinic of King Abdulaziz University Hospital were included in the study. All the patients were males. The mean age was
12.4 (SD 2.2) years (range 10-17 years). The symptoms mentioned by all the patients were itching, redness, photophobia, and tearing. Each patient underwent complete ophthalmic examination, and the corneal and conjunctival changes were noted and recorded. All patients had the limbal form of the disease characterised by broad gelatinous infiltrates of the limbus. Limbal conjunctival biopsy specimens were obtained from each patient. None of the patients was on topical therapy before obtaining the biopsy. In addition, six limbal conjunctival biopsy specimens were obtained from patients undergoing strabismus surgery without obvious inflammation and served as controls. The controls were from the same age group, and were four males, and two females.

\section{IMMUNOHISTOCHEMICAL STAINING}

The conjunctival biopsy specimens were immediately snap frozen in Tissue-Tek optimum cutting temperature (OCT) compound (Miles Laboratories, IN, USA) and maintained at $-80^{\circ} \mathrm{C}$ until use. For immunohistochemistry, $5 \mu \mathrm{m}$ serially cut cryostat sections were dried overnight at room temperature, fixed in absolute acetone for 10 minutes, and then treated with $2 \%$ hydrogen peroxide in methanol for 3 minutes to block endogenous peroxidase activity. After rinsing three times in phosphate buffered saline (PBS) at $\mathrm{pH} 7.2$ for 15 minutes, the slides were incubated for $30 \mathrm{~min}$ utes with the monoclonal and polyclonal antibodies listed in Table 1. Optimal concentrations of all antibodies used were determined in pilot experiments. After a wash with PBS, the sections were incubated for 30 minutes with EnVision+, Peroxidase, Rabbit, or EnVision+, Peroxidase, Mouse (Dako, CA, USA). These are goat anti-rabbit or antimouse immunoglobulins conjugated to peroxidase labelled dextran polymer. The products react with rabbit immunoglobulins or with mouse immunoglobulins of all classes and minimally with human immunoglobulins thus allowing better visualisation. The slides were washed again with PBS and the reaction product was visualised by incubation for 10 minutes in $0.05 \mathrm{M}$ acetate buffer at $\mathrm{pH} 4.9$, containing $0.05 \%$ 3-amino-9-ethylcarbazole (Sigma) and $0.01 \%$ hydrogen peroxide, resulting in bright red immunoreactive sites. The slides were faintly counterstained with Harris haematoxylin. Finally, the sections were rinsed with distilled water and coverslipped with glycerol. Omission or substitution of the primary antibody with an irrelevant antibody of the same species was used as a negative control.

\section{DOUBLE IMMUNOHISTOCHEMISTRY}

To examine the phenotype of inflammatory cells expressing chemokines, cryostat sections were studied by sequential double immunohistochemistry. In addition, sequential double immunohistochemistry was used to confirm the expression of RANTES and eotaxin by vascular endothelial cells. Colocalisation studies were performed in three VKC specimens. After rinsing the slides with PBS, they were incubated for 30 minutes with the appropriate 


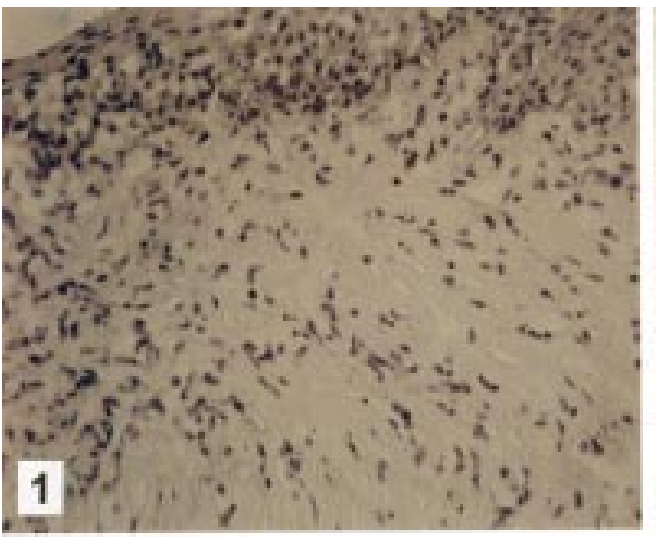

Figure 1 (1) Vernal keratoconjunctivitis control slide, treated identically, using an irrelevant monoclonal antibody showing no staining ( $\times 300)$. (2) Immunohistochemical staining for eotaxin of conjunctiva from a normal control subject showing weak cytoplasmic expression in the superficial epithelial layers $(\times 500)$. (3) Vernal

keratoconjunctivitis. Immunohistochemical staining for eotaxin showing intense cytoplasmic staining in all epithelial cells and staining on the vascular endothelium (arrows) (×500).

monoclonal antibody to determine cellular phenotype (CD68, CD3, and factor VIII related antigen) and rinsed again in PBS. Subsequently, the sections were incubated for 30 minutes with Envision +, Peroxidase, Mouse (Dako, CA, USA) and washed again with PBS. Then, the reaction product was visualised by incubation for 10 minutes in $0.05 \mathrm{M}$ acetate buffer at $\mathrm{pH} 4.9$, containing $0.05 \%$ 3-amino-9ethylcarbazole (Sigma) and $0.01 \%$ hydrogen peroxide, resulting in red immunoreactive staining. Afterwards the sections were rinsed with PBS, washed with distilled water, and incubated for 30 minutes with the monoclonal anti-human RANTES antibody. After a wash with PBS, the sections were incubated for 30 minutes with a biotin labelled rabbit antimouse antibody, followed by a monoclonal anti-biotin-alkaline phosphatase conjugate (Sigma). The blue reaction product was developed using fast blue BB salt (4-benzoylamino2.5-diethoxybenzene-diazonium chloride) (Sigma-Aldrich, Bornem, Belgium) for 5 minutes.
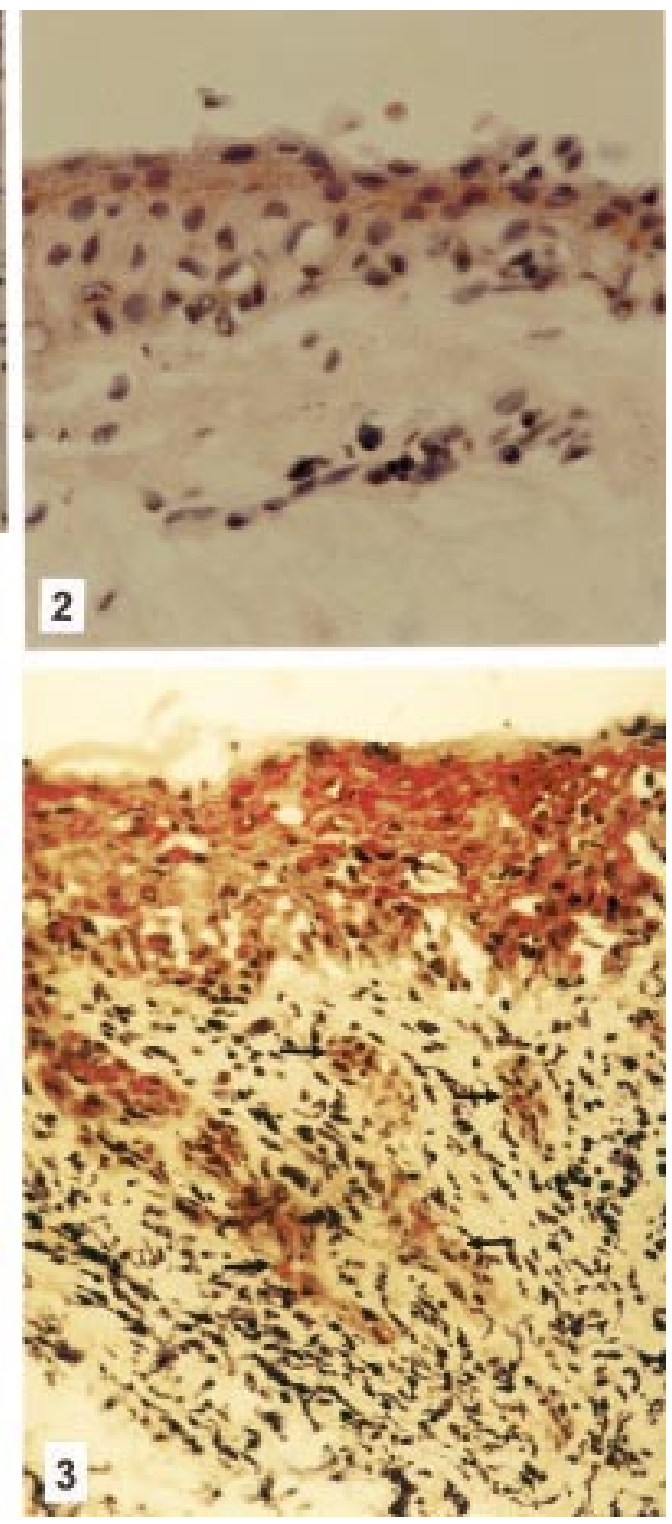

QUANTITATION

Cells were counted in five fields that were chosen on the basis of the presence of an adequate number of inflammatory cells. We ignored fields in which no positively stained cells were present. We used an eye piece calibrated grid with $25 \times$ magnification. With this magnification and calibration, we counted the cells present in an area of $0.155 \times 0.155 \mathrm{~mm}$. For the colocalisation studies, inflammatory cells expressing both chemokines and CD68, or CD3 were counted and expressed as a percentage of cells expressing chemokines.

STATISTICAL ANALYSIS

Means (SD) were calculated for each cell type in VKC and control specimens. The $t$ test was used to analyse the statistical significance of differences between mean numbers of cells stained with different chemokine antibodies in patients and controls. One way analysis of variance (ANOVA) was used to analyse the statistical significance of differences between mean numbers of cells stained with different chem- 


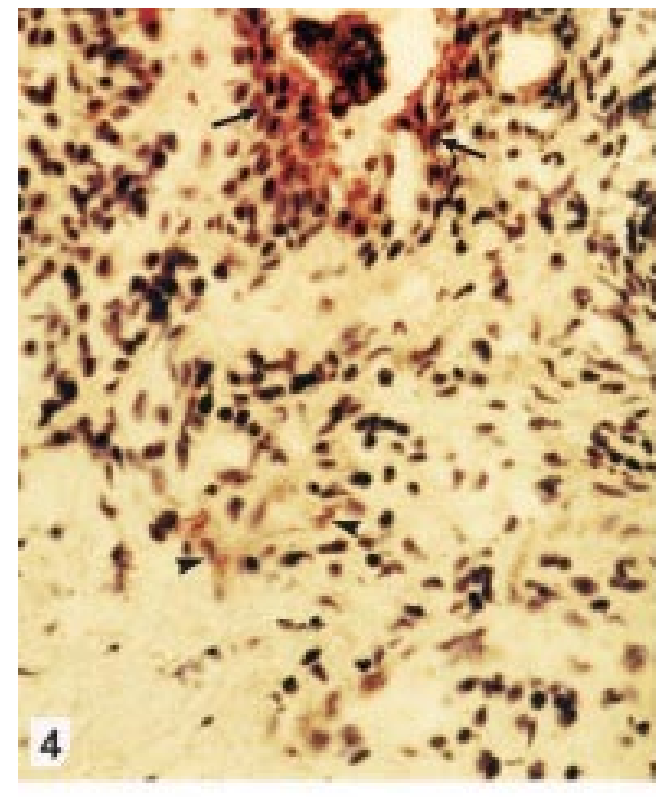

Figure 2 (4) Vernal keratoconjunctivitis.

Immunohistochemical staining for RANTES showing cytoplasmic staining in epithelial cells (arrows) and staining on the vascular endothelium (arrowheads) (×500). (5) Vernal keratoconjunctivitis.

Immunohistochemical staining for $M C P-1$ showing cytoplasmic staining in inflammatory cells (arrows)

$(\times 500)$. (6) Vernal keratoconjunctivitis. Double

immunohistochemical staining for RANTES (blue), and CD68 (red) showing RANTES positive cells coexpressing CD68 marker (arrows) $(\times 1200)$.

okine antibodies in VKC specimens. PostANOVA pairwise multiple comparisons were done using the Bonferroni test. ANOVA was conducted using program 7D from the BMDP Statistical Package. Logarithm transformation was used to reduce variances during ANOVA. The differences were considered significant if the $\mathrm{p}$ value was $<0.05$.

\section{Results}

There was no staining in the negative control slides (Fig 1(1)). In normal conjunctiva, the surface epithelial cells demonstrated weak cytoplasmic staining for eotaxin (Fig 1(2)). Conjunctival epithelial cells of controls were negative for RANTES, MCP-1, MCP-2, and MCP-3. Few inflammatory cells in the perivascular areas showed cytoplasmic staining for RANTES, MCP-1, MCP-2, and MCP-3. No immunoreactivity was seen on the vascular endothelium.

Conjunctival specimens from VKC patients showed intense cytoplasmic staining for eotaxin in all epithelial cells (Fig 1(3)). Patchy cytoplasmic RANTES staining was seen in the epithelium which was most intense in the superficial epithelial layers (Fig 2(4)). The epi-

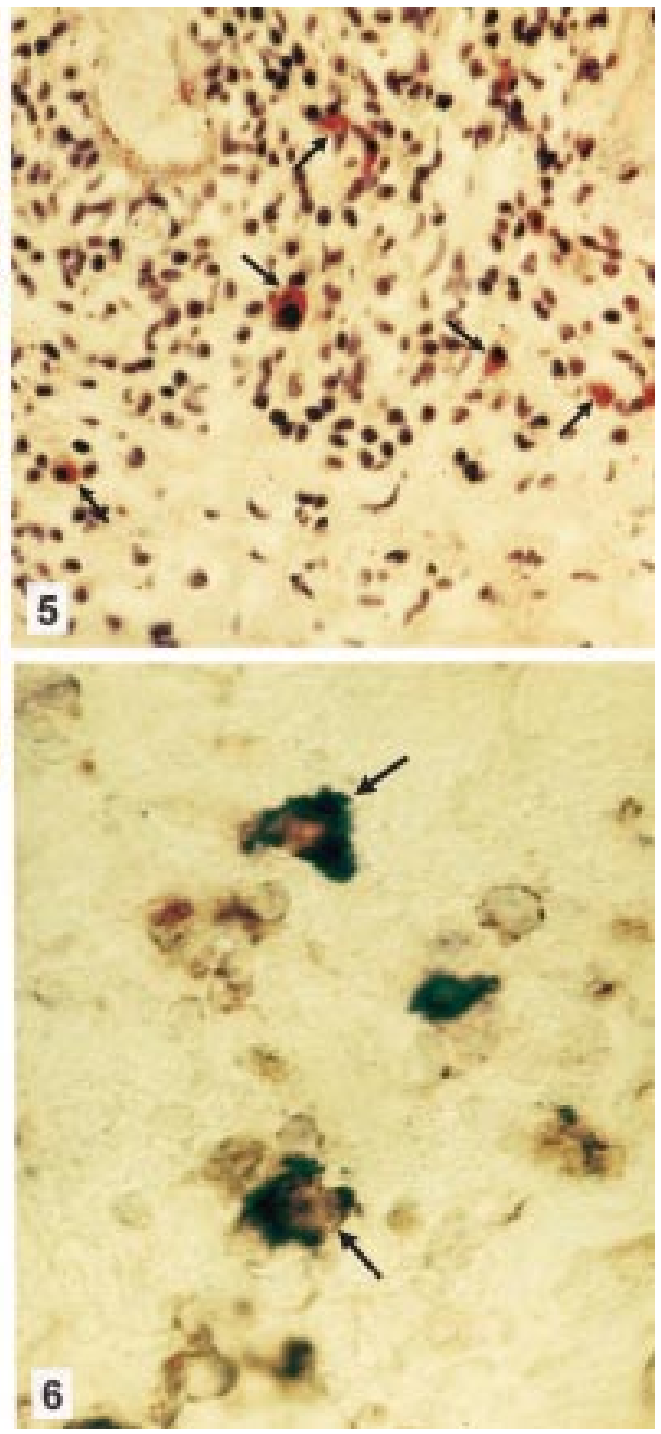

thelial cells did not express MCP-1, MCP-2, and MCP-3. Eotaxin (Fig 1(3)) and RANTES (Fig 2(4)) staining was observed on the vascular endothelium expressing factor VIII related antigen mainly in the upper substantia propria adjacent to the epithelium. The vascular endothelium did not express MCP-1, MCP-2, and MCP-3. In the substantia propria, inflammatory cells expressing cytoplasmic RANTES, eotaxin, MCP-1 (Fig 2(5)), MCP-2, and MCP-3 were noted.

VKC specimens showed statistically significant higher counts than control specimens for inflammatory cells expressing RANTES, eotaxin, MCP-1, and MCP-3 (Table 2). Statistically insignificant higher numbers of inflammatory cells expressing MCP-2 were noted in VKC specimens compared with control specimens. In VKC specimens, the numbers of inflammatory cells expressing RANTES were higher than the numbers of inflammatory cells expressing eotaxin, MCP-1, MCP-2, and MCP-3. The mean values of the five groups differed significantly ( $p<0.001$, ANOVA). Furthermore, post-ANOVA pairwise multiple comparisons showed that the numbers of inflammatory cells expressing RANTES were 
Table 2 Number of inflammatory cells expressing chemokines in VKC and control specimens (mean (SD))

\begin{tabular}{llll}
\hline Chemokine & Control $(n=6)$ & VKC $(n=9)$ & $p$ Value \\
\hline RANTES & $2.0(1.8)$ & $16.3(3.6)$ & $<0.001$ \\
Eotaxin & $0.0(0.0)$ & $6.6(3.9)$ & 0.0028 \\
MCP-1 & $2.8(2.6)$ & $9.0(4.4)$ & 0.0092 \\
MCP-2 & $1.0(1.7)$ & $5.7(5.5)$ & 0.2968 (NS) \\
MCP-3 & $1.2(1.3)$ & $11.1(4.0)$ & $<0.001$
\end{tabular}

VKC = vernal keratoconjunctivitis; RANTES = regulated upon activation, normal $\mathrm{T}$ cell expressed and secreted; $\mathrm{MCP}=$ monocyte chemotactic protein.

NS $=$ not significant

significantly higher than the numbers of inflammatory cells expressing eotaxin, MCP-1, and MCP-2 (all $\mathrm{p}$ values $<0.001, t$ test). Double immunohistochemistry to confirm the phenotype of chemokine positive inflammatory cells showed that the majority of mononuclear cells expressing RANTES were CD68 positive monocytes/macrophages (mean $83 \%$ (SD $7.3 \%), \mathrm{n}=3$ ) (Fig 2(6)). Smaller numbers of inflammatory cells expressing RANTES were CD3 positive $\mathrm{T}$ cells (mean $7 \%(2.9 \%), \mathrm{n}=3$ ). Similarly, the majority of inflammatory cells expressing eotaxin, MCP-1, and MCP-3 were CD68 positive monocytes/macrophages (mean $58 \%(5 \%), 81 \%(8.1 \%)$, and $78 \%(6.5 \%)$, respectively, $\mathrm{n}=3$ ). Smaller numbers of inflammatory cells expressing eotaxin, MCP-1, and MCP-3 were CD3 positive T cells (mean $7 \%(3 \%), 5.3 \%(3 \%)$, and $8 \%(2 \%)$, respectively, $\mathrm{n}=3$ ). Other chemokine positive inflammatory cells were not identified by the two markers used.

\section{Discussion}

Eotaxin, a potent CC chemokine originally purified from the bronchoalveolar lavage fluid from allergen challenged guinea pigs, is a potent and selective eosinophil chemoattractant. ${ }^{22-24}$ In addition, eotaxin is a potent activator of the respiratory burst and actin polymerisation of eosinophils. ${ }^{24}$ Eotaxin, therefore, plays an important part not only by attracting eosinophils to the site of inflammation but also by damaging tissue by its capacity to induce the release of reactive oxygen species.

From clinical specimens, it has been previously demonstrated that eotaxin mRNA and immunoreactivity were constitutively expressed by bronchial epithelium, ${ }^{25}{ }^{26}$ and nasal epithelium $^{27}$ from normal individuals. It is suggested that the constitutive expression of eotaxin in healthy conditions regulates the physiological trafficking of eosinophils. ${ }^{28}$ In conjunctival biopsies from normal individuals, there was a constitutive, weak expression of eotaxin immunoreactivity in the epithelial layer. Compared with normal conjunctiva, the conjunctiva from patients with VKC showed strong expression of eotaxin immunoreactivity in the epithelial layer, stromal inflammatory cells, and vascular endothelial cells. Previous studies have documented the increased expression of eotaxin mRNA and immunoreactivity within the airways of asthmatic individuals, ${ }^{25} 26$ and in nasal biopsy specimens from individuals with allergic rhinitis. ${ }^{27}$ In subjects with allergic rhinitis allergen challenge of the nasal mucosa resulted in a local upregulation of eotaxin expression. ${ }^{27}$ In the airways of asthmatic individuals, the expression of eotaxin mRNA was significantly correlated with the numbers of eosinophils present. ${ }^{25}$ Our observations are consistent with previous data in bronchial and nasal biopsy specimens from patients with asthma and allergic rhinitis which suggested that the majority of cells expressing eotaxin mRNA and protein were epithelial cells, endothelial cells, and inflammatory cells and that the predominant eotaxin bearing inflammatory cells were CD68 positive macrophages. ${ }^{25-27}$ Other inflammatory cells expressing eotaxin were eosinophils, $\mathrm{T}$ cells, mast cells, and neutrophils. ${ }^{26} 27$

RANTES is a potent chemoattractant for eosinophils, basophils, monocytes/macrophages, and $\mathrm{CD} 45 \mathrm{RO} / \mathrm{CD}^{+}$memory $\mathrm{T}$ lymphocytes. ${ }^{29-33}$ In addition, it exhibits pleiotropic effects on a variety of target cell types, including activation of eosinophils, ${ }^{31}$ and $\mathrm{T}$ lymphocytes, ${ }^{34}$ induction of eosinophil transendothelial migration in the extracellular spaces in vitro that was potentiated by pre-exposure of eosinophils to IL- $5,{ }^{35}$ and induction of histamine release from basophils. ${ }^{36}$ Further, RANTES seems to stimulate $\operatorname{IgE}^{+}$tonsillar B cells for IgE production. ${ }^{37}$ Thus RANTES may be involved in both acute and chronic stages of allergic inflammation.

In the present study, we have demonstrated that the conjunctival epithelial cells from patients with VKC showed cytoplasmic expression of RANTES. Normally, conjunctival epithelial cells do not express RANTES. Furthermore, we found that in VKC vascular endothelial cells and inflammatory cells in the substantia propria expressed RANTES. The majority of these inflammatory cells were $\mathrm{CD} 8^{+}$monocytes/macrophages. Similarly, positive immunohistochemical staining for RANTES was detected in the conjunctival epithelium from one patient with atopic keratoconjunctivitis. ${ }^{38}$ In addition, RANTES has been detected by immunohistochemistry in the epithelial and vascular endothelial cells of bronchial biopsy tissues obtained from asthmatic patients, ${ }^{39}$ and in epithelial cells, vascular endothelial cells, and mononuclear cells of nasal polyps. ${ }^{40}$ After local allergen provocation of the nasal mucosa, the majority of RANTES mRNA $^{+}$cells were macrophages. ${ }^{41}$

Factors regulating the expression of eotaxin and RANTES by conjunctival epithelial cells, and vascular endothelial cells in VKC are incompletely understood. Other cytokines may be involved in regulating eotaxin and RANTES production. Several studies demonstrated the production of eotaxin, ${ }^{42}$ and RANTES $^{39} 43$ by bronchial epithelial cells stimulated by IL-1 $\beta$ and tumour necrosis factor $\alpha(\mathrm{TNF} \alpha)$. RANTES production was demonstrated in nasal epithelial cells and endothelial cells stimulated by IL-1 $\beta$, and $\mathrm{TNF}^{44}{ }^{44}$ In addition, $\mathrm{TNF} \alpha$ induced RANTES production in a conjunctival epithelial cell line. ${ }^{38}$ Possible sources for these cytokines include macrophages ${ }^{45}$ which are present in abundance in VKC, ${ }^{5}$ mast cells, ${ }^{46}$ and basophils. ${ }^{47}$ Our data indicate that con- 
junctival epithelium is not only a structural barrier but it is also a source of chemokines able to modulate inflammation. Conjunctival epithelial cells produce eotaxin and RANTES that recruit a pattern of cells including eosinophils, $\mathrm{T}$ lymphocytes, basophils, and monocytes that are known to migrate to the conjunctiva in VKC. It is noteworthy that the greatest accumulation of inflammatory cells is seen adjacent to the epithelium.

In the present study, we detected cytoplasmic expression of MCP-1, MCP-2, and MCP-3 by inflammatory cells in the substantia propria. The majority of these inflammatory cells were monocytes/macrophages. However, the numbers of $\mathrm{MCP}-2^{+}$inflammatory cells in VKC specimens and normal conjunctival biopsy specimens did not differ significantly. MCP-1, MCP-2, and MCP-3 have originally been identified as potent monocyte chemotactic proteins. ${ }^{48} \mathrm{MCP}-1$ is a potent histamine releasing factor for basophils, ${ }^{49}$ but does not attract or activate eosinophils. MCP-3 causes eosinophil and basophil chemotaxis, and stimulates histamine release from human basophils. ${ }^{50} \mathrm{MCP}-2$ has been found to share the bioactivity profile with MCP-3 rather than with MCP-1. However, it is a weaker inducer of chemotaxis and release responses in basophils and eosinophils than MCP-3. ${ }^{51}$ Several clinical studies demonstrated that the bronchoalveolar lavage fluid from patients with asthma contained elevated concentrations of MCP$1 .^{52}{ }^{53}$ Allergen provoked a significant increase in $\mathrm{mRNA}^{+}$cells for $\mathrm{MCP}-3$ which paralleled the kinetics of early eosinophil response in the skin of atopic subjects. ${ }^{54}$ Furthermore, increased mRNA expression for MCP-3 was detected in bronchial biopsies in asthmatic patients. ${ }^{55}$

All chemokines act via $G$ protein coupled, 7 -transmembrane-domain receptors. ${ }^{20}$ The cellular targets of a chemokine are determined by the recognition of one or more receptors, and whether these are functionally expressed on different leucocyte populations. The CC chemokine receptor 3 (CCR3) used by eotaxin is found on eosinophils, ${ }^{26}$ basophils, ${ }^{56}$ and TH2-type lymphocytes. ${ }^{57}$ Unlike other members of the CC chemokines which generally act on several receptors, eotaxin only signals via the CCR3 explaining the high specificity of eotaxin for eosinophils. Other CC chemokines-for example, RANTES, MCP-3, and MCP-4 also bind to the CCR3 but with lower affinity. ${ }^{589}$ In light of its prominent role in eosinophil, basophil, and TH2-type lymphocyte chemotaxis, CCR3 is a promising target for the development of new antiallergic drugs to block selectively the accumulation of the effector cells of allergic inflammation. ${ }^{56} 60-63$

In conclusion, this study has demonstrated that increased expression of the CC chemokines RANTES, eotaxin, MCP-1, and MCP-3 is evident in the conjunctiva from patients with VKC, and that conjunctival epithelial cells are capable of synthesising RANTES and eotaxin. The expression of these chemokines may in part be responsible for the conjunctival accu- mulation of eosinophils, basophils, and mononuclear cells observed in VKC. Small molecule antagonists of chemokine receptors may therefore be ideal inhibitors of eosinophil recruitment to conjunctiva, and thereby prevent the tissue damage mediated by eosinophilic toxic granule proteins and reactive oxygen species.

This work was supported in part by the Fund for Scientific Research of Flanders (FWO-Vlaanderen). Sofie Struyf is a research assistant of the FWO-Vlaanderen.

The authors thank Ms Christel Van den Broeck for technical assistance, Mr Dustan Kangave for statistical assistance, and Ms assistance, Mr Dustan Kangave for statistical
Connie B Unisa-Marfil for secretarial work.

1 Buckley RJ. Vernal keratoconjunctivitis. Int Ophthalmol Clin 1988;28:303-8.

2 Allansmith MR, Ross RN. Ocular allergy. Clin Allergy 1988; 18:1-13.

3 Abu El-Asrar AM, Van den Oord JJ, Geboes K, et al. Immunopathological study of vernal keratoconjunctivitis. Graefes Arch Clin Exp Ophthalmol 1989;227:374-9.

4 Abu El-Asrar AM, Tabbara KF, Geboes K, et al. An immunohistochemical study of topical cyclosporine in vernal keratoconjunctivitis. Am f Ophthalmol 1996;121:15661

5 Abu El-Asrar AM, Geboes K, Al-Kharashi S, et al. Adhesion molecules in vernal keratoconjunctivitis. $\mathrm{Br} f$ Ophthalmol 1997;81:1099-106.

6 Maggi E, Biswas P, Del Prete G, et al. Accumulation of Th-2-like helper $T$ cells in the conjunctiva of patients with vernal conjunctivitis. F Immunol 1991;146:1169-74.

7 Montan PG, Biberfeld PJ, Scheynius A. IgE, IgE receptors, and other immunocytochemical markers in atopic and nonatopic patients with vernal keratoconjunctivitis. $O p h-$ thalmology 1995;102:725-32.

8 Collin HB, Allansmith MR. Basophils in vernal conjunctivitis in humans: an electron microscopic study. Invest Ophthalmol Vis Sci 1977;16:858-65.

9 Trocme SD, Kephart GM, Bourne WN, et al. Eosinophil granule major basic protein deposition in corneal ulcers associated with vernal keratoconjunctivitis. Am f Ophthalmol 1993;115:640-3.

10 Trocme SD, Hallbarg CK, Gill KS, et al. Effects of eosinophil granule proteins on human corneal epithelial cell viability and morphology. Invest Ophthalmol Vis Sci 1997;38:593-9.

11 Trocme SD, Kephart GM, Allansmith MR, et al. Eosinophil granule major basic protein in vernal keratoconjunctivitis and contact lens-associated giant papillary conjunctivitis. Am f Ophthalmol 1989;108:57-63.

12 Kay AB, Barata L, Meng Q, et al. Eosinophils and eosinophil-associated cytokines in allergic inflammation. Int Arch Allergy Immunol 1997;113:196-9.

13 Walsh GM, Mermed JJ, Hartness A, et al. Human eosinophil, but not neutrophil, adherence to IL-1 stimulated human umblical vascular endothelial cells is very lateantigen 4 dependent. F Immunol 1991;146:3419-23.

14 Thornhill MH, Wellicome SM, Mahiouz DL, et al. Tumor necrosis factor combines with IL-4 or IFN-gamma to selectively enhance endothelial cell adhesiveness for T cells. The contribution of vascular cell adhesion molecule-1 The contribution of vascular cell adhesion molecule-1 dependent and indep

15 Bochner BS, Klunk DA, Sterbinsky SA, et al. Interleukin-13 selectively induces vascular cell adhesion molecule-1 VCAM-1) expression in human endothelial cells. F Immunol 1995;154:799-803.

16 Bacon AS, McGill JI, Anderson DF, et al. Adhesion molecules and relationship to leukocyte levels in allergic eye disease. Invest Ophthalmol Vis Sci 1998;39:322-30.

17 Ciprandi G, Buscaglia S, Pesce G, et al. Allergic subjects express intercellular adhesion molecule-1 (ICAM-1 or CD54) on epithelial cells of conjunctiva after allergen challenge. F Allergy Clin Immunol 1993;91:783-92.

18 Ebisawa M, Liu MC, Yamada T, et al. Eosinophil transendothelial migration induced by cytokines II. The potentiation of eosinophil transendothelial migration by eosinophilactive cytokines. F Immunol 1994;152:4590-7.

19 Alam R. Chemokines in allergic inflammation. F Allergy Clin Immunol 1997;99:273-7.

20 Rollins B. Chemokines. Blood 1997;90:909-28.

21 Wells TNC, Proudfoot AEI. Chemokine receptors and their antagonists in allergic lung disease. Inflamm Res 1999;48: 353-62.

22 Griffiths-Johnson DA, Collins PD, Rossi AG, et al. The chemokine, eotaxin, activates guinea-pig eosinophils in vitro and causes their accumulation into the lung in vivo. Biochem Biophys Res Commun 1993;197:1167-72.

23 Jose PJ, Griffiths ID, Collins PD, et al. Eotaxin: a potent eosinophil chemoattractant cytokine detected in a guinea pig model of allergic airways inflammation. 7 Exp Med 1994;179:881-7.

24 Elsner J, Hochstetter R, Kimmig D, et al. Human eotaxin represents a potent activator of the respiratory burst of represents a potent activator of the respiratory burs
human eosinophils. Eur f Immunol 1996;26:1919-25.

25 Taha RA, Minshall EM, Miotto D, et al. Eotaxin and monocyte chemotactic protein- 4 mRNA expression in small airways of asthmatic and nonasthmatic individuals. $\mathcal{F}$ Allergy Clin Immunol 1999;103:476-83. 
26 Ying S, Robinson DS, Meng O, et al. Enhanced expression of eotaxin and CCR3 mRNA and protein in atopic asthma. Association with airway hyperresponsiveness and predomi-
nant colocalization of eotaxin mRNA to bronchial nant colocalization of eotaxin mRNA to bronchial 27:3507-16.

27 Minshall EM, Cameron L, Lavigne F, et al. Eotaxin mRNA and protein expression in chronic sinusitis and allergeninduced nasal responses in seasonal allergic rhinitis. $A m f$ Respir Cell Mol Biol 1997;17:683-90.

28 Matthews AN, Friend DS, Zimmermann N, et al. Eotaxin is required for the baseline level of tissue eosinophils. Proc Natl Acad Sci USA 1998;95:6273-8.

29 Schall T. Biology of the RANTES/SIS cytokine family. Cytokine 1992;3:165-83.

30 Kameyoshi Y, Dörschner A, Mallet A, et al. Cytokine RANTES released by thrombin-stimulated platelets is a potent attractant for human eosinophils. If Immunol potent attractant

31 Alam R, Stafford S, Forsythe P, et al. RANTES is a chemotactic and activating factor for human eosinophils. F Immunol 1993;150:3442-7.

32 Beck LA, Dalke S, Leiferman KM, et al. Cutaneous injection of RANTES causes eosinophil recruitment. Comparison of nonallergic and allergic subjects. F Immuno 1997; 159:2962-72.

33 Kuna P, Alam R, Ruta U, et al. RANTES induces nasa mucosal inflammation rich in eosinophils, basophils, and lymphocytes in vivo. Am $\mathcal{F}$ Respir Crit Care Med 1998;157 $873-9$

34 Bacon K, Premack B, Gardner P, et al. Activation of dual T cell signalling pathways by the chemokine RANTES. Science 1995;269:1727-30.

35 Ebisawa M, Yamada T, Bickel C, et al. Eosinophil transendothelial migration induced by cytokines III. Effect of the chemokine RANTES. F Immunol 1994;153:2153-60.

36 Kuna P, Reddigari SR, Schall TJ, et al. RANTES, a monocyte and $\mathrm{T}$ lymphocyte chemotactic cytokine releases cyte and T lymphocyte chemotactic cytokine releases
histamine from human basophils. F Immunol 1992;149: 636-42.

37 Kimata H, Yoshida A, Ishioka C, et al. RANTES and macrophage inflammatory protein-1 $\alpha$ selectively enhance IgE and IgG4 production. F Exp Med 1996;183:2397-402.

38 Fukagawa K, Saito $\mathrm{H}$, Tsubota, et al. RANTES production in a conjunctival epithelial cell line. Cornea 1997;16:56470.

39 Wang JH, Devalia JL, Xia C, et al. Expression of RANTES by human bronchial epithelial cells in vitro and in vivo and the effect of corticosteroids. Am 7 Respir Cell Mol Biol 1996;14:27-35.

40 Beck LA, Stellato C, Beal D, et al. Detection of the chemokine RANTES and endothelial adhesion molecules in nasal polyps. F Allergy Clin Immunol 1996;98:766-80.

41 Rajakulasingam K, Hamid Q, O'Brien F, et al. RANTES in human allergen-induced rhinitis. Cellular source and relation to tissue eosinophilia. Am $\mathcal{F}$ Respir Crit Care Med 1997 ; 155:696-703.

42 Lilly CM, Nakamura H, Kesselman H, et al. Expression of eotaxin by human lung epithelial cells: induction by cytokines and inhibition by glucocorticoids. 7 Clin Invest cytokines and inhit

43 Stallato C, Beck LA, Gorgone GA, et al. Expression of the chemokine RANTES by a human bronchial epithelial cell line modulation by cytokines and glucocorticoids. F Immunol 1995; 155:410-8.

44 Terada N, Maesako KI, Hamano N, et al. RANTES production in nasal epithelial cells and endothelial cells. $f$ Allergy Clin Immunol 1996;98:S230-7.

45 Sisson SD, Dinarello CA. Production of interleukin-1 alpha, interleukin-1 beta and tumor necrosis factor by human mononuclear cells stimulated with granulocytemacrophage colony-stimulating factor. Blood 1988;72. 1368-74.
46 Möller A, Henz BM, Grützkau A, et al. Comparative cytokine gene expression: regulation and release by human cytokine gene expression: regulation and

47 Steffen M, Abboud M, Potter GK, et al. Presence of tumor necrosis factor or a related factor in human basophil mast cells. Immunology 1989;66:445-50.

48 Van Damme J, Proost P, Lenaerts J-P, et al. Structural and functional identification of two human, tumor-derived monocyte chemotactic proteins (MCP-2 and MCP-3) belonging to the chemokine family. $\mathcal{F}$ Exp Med 1992;176: $59-65$.

49 Bischoff SC, Krieger M, Brunner T, et al. Monocyte chemotactic protein-1 is a potent activator of human basophils. 7 Exp med 1992;175:1271-5.

50 Dahinden CA, Geiser T, Brunner T, et al. Monocyte chemotactic protein 3 is a most effective basophil - and eosinophil-activating chemokine. f Exp Med 1994;179: 751-6.

51 Weber $M$, Uguccioni $M$, Ochensberger B, et al. Monocyte chemotactic protein MCP-2 activates human basophil and eosinophil leukocytes similar to MCP-3. f Immunol 1995;154:4166-72.

52 Alam R, York J, Boyars M, et al. Increased MCP-1, RANTES, and MIP-1 alpha in bronchoalveolar lavage fluid of allergic asthmatic patients. Am F Respir Crit Care Med 1996;153:1398-404

53 Holgate ST, Bodey KS, Janezic A, et al. Release of RANTES, MIP-1 alpha, and MCP-1 into asthmatic airways following endobronchial allergen challenge. Am f Respir Crit Care Med 1997;156:1377-83.

54 Ying S, Taborda-Barata L, Meng Q, et al. The kinetics of allergen-induced transcription of messenger RNA for monocyte chemotactic protein-3 and RANTES in the skin of human atopic subjects: relationship to eosinophil, T cell, and macrophage recruitment. 7 Exp Med 1995;181:21539.

55 Humbert M, Ying S, Corrigan C, et al. Bronchial mucosal expression of the genes encoding chemokines RANTES and MCP-3 in symptomatic atopic and nonatopic asthmatics: relationship to the eosinophil-active cytokines interleukin (IL) -5, granulocyte macrophage - colony interleukin (IL) -5, granulocyte macrophage - colony stimulating fact

56 Uguccioni M, MacKay CR, Ochensberger B, et al. High expression of the chemokine receptor CCR3 in human blood basophils. Role in activation by eotaxin, MCP-4, and other chemokines. F Clin Invest 1997;100:1137-43.

57 Sallusto F, MacKay CR, Lanzavecchia A. Selective expression of the eotaxin receptor CCR3 by human T helper 2 cells. Science 1997;277:2005-7.

58 Daugherty BL, Siciliano SJ, De Martino JA, et al. Cloning, expression, and characterization of the human eosinophil eotaxin receptor. F Exp Med 1996;183:2349-54.

59 Ponath PD, Quin S, Post TW, et al. Molecular cloning and characterization of a human eotaxin receptor expressed selectively on eosinophils. $\mathcal{F}$ Exp Med 1996;183:2437-48.

60 Heath H, Quin S, Rao P, et al. Chemokine receptor usage by human eosinophils. The importance of CCR3 demonstrated using an antagonistic monoclonal antibody. 7 Clin Invest 1997:99:178-84.

61 Sabroe I, Conroy DM, Gerard NP, et al. Cloning and characterization of the guinea pig eosinophil eotaxin receptor, $\mathrm{C}-\mathrm{C}$ chemokine receptor -3 : blockage using a monoclonal antibody in vivo. F Immunol 1998;161:6139-47.

62 Elsner J, Petering H, Höchstetter R, et al. the CC chemokine antagonist Met-RANTES inhibits eosinophil effector functions through the chemokine receptors CCR1 and CCR3. Eur F Immunol 1997;27:2892-8.

63 Struyf S, Proost P, Schols D, et al. CD26/dipeptidylpeptidase IV down-regulates the eosinophil chemotactic potency, but not the anti-HIV activity of human eotaxin by affecting its interaction with CC chemokine receptor 3,7 Immunol 1999;162:4903-9. 